Марија М. Ђорђевић*

Рударско-геолошки факултет

Универзитет у Београду https://doi.org/10.18485/analiff.2020.32.1.3 821.111(73).09Морисон T, 821.111(73).09 Барт Џ. Originalni naučni rad Primljen: 03.02.2020. Prihvaćen: 12.06.2020.

\title{
ТОНИ МОРИСОН КРОЗ ПРИЗМУ ЏОНА БАРТА: ДА ЛИ ЈЕ ВОљЕНА РОМАН ПОСТМОДЕРНЕ?
}

Тони Морисон и Џон Барт спадају у категорију писаца који су својим делима не само изменили дотадашња поимања шта једно књижевно дело јесте и треба да буде, већ су утицали и на саму науку о књижевности, уносећи у ово поље идиосинкратичне мотиве, идеје и начине писања, заувек мењајући начин на који читамо и анализирамо књижевна дела. Узимајући све изречено у обзир, требало би да следи да оба писца буду дефинисана као писци постмодерне, међутим, за Тони Морисон то није толико евидентно. Док се Џон Барт сматра једним од зачетника англофоног постмодернизма и његово име је најчешће синоним за исти, Тони Морисон се и даље не даје отворен приступ овом правцу, већ се ставља под свепокривајући вео савременог романа. Овај рад ће покушати да кроз критеријуме постмодерног писања Џона Барта које је објавио у својим монументалним есејима о кињжевности постмодерне, а на основу романа Вољена Тони Морисон, ову списатељицу дефинише управо као оно што аутор сматра да она јесте - прави представник постмодернизма и постмодерног романа.

Кључне речи: Тони Морисон, Џон Барт, постмодернизам, роман, наратив

\section{УВОД}

Књижевност постмодернизма је амалгам не само различитих књижевних форми и стилова који рефлектују став постојећег или пак непостојећег аутора према теми о којој пише, већ и мноштва разноликих идеја варирају од описа нечега терестријалног, на граници баналног, до врсте металингвистичких поимања самог језика, културе, али и свих психолошких процеса који ту ступају на сцену. Узевши све претходно изречено у обзир, лако је закључити да бавити се књижевношћу постмодернизма и покушати било какву класификацију унутар

* Ђушина 7; marija.djordjevic@rgf.bg.ac.rs 
исте је, у најмању руку, захтеван подухват. Управо када је у питању класификација и вечно питање шта је то што дефинише књижевност постмодернизма на сцену ступају најпре Џон Барт, као један од писаца који је успео да постане и остане класификован не само као један од представника постмодерног писања, већ и један од зачетника теорије постмодернизма, а потом и Тони Морисон, списатељица која је својим радом и делом редефинисала канон у оквиру ког је иницијално била смештена, да би временом постала један од најзначајнијих писаца свог времена. Да ли је то време постмодернизам и да ли је самим тим и Тони Морисон списатељица постмодерне? Ми сматрамо да јесте. Не само због тема којима се бави и начином на који то чини, већ и због саме намере њених романа, чему је овај рад и посвећен. Уколико се фокусирамо само на роман Вољена, који и јесте у фокусу овог рада, не само да Морисонова користи бројне технике које се асоцирају са стилом писања постмодерниста (које ће детаљно бити обрађене даље у раду) већ и сама амбиваленција и несигурност поруке романа упућује на постмодернистичке тврдње о непостојаности било чега, а посебно истинитости наметнутих великих наратива, од којих је можда и највећи наратив историје (који би се и сам по себи могао сматрати постмодерним, с обзиром на непостојање једног свезнавајућег аутора, али и на његову/њену свеприсутност кроз колективну свест оних који ту историју су живели, то јест, живе).

Док се данас воде дебате око тога да ли Тони Морисон јесте или није постмодерна књижевница, сама списатељица је имала потешкоћа да себе види као књижевницу која и ствара и пише нова дела -

И йек након своје ииреће књиіе, Соломонова иесма, коначно сам рекла [...] gа се овиме бавим. До йаgа сам найисала иири књиіе. Тек након шито сам завршила „Соломонову иесму" сам йомислила-можgа се само овиме бавим. Јер, ире йоїа, увек сам іоворила gа сам ја лекйор који йакође йише књиіе или йреgавач који тиакође иичше. Никаgа нисам рекла gа сам ӥисаи. (ииитирано у Duvall, 2000: 71)²

\footnotetext{
1 Наводнике додала ауторка.

2 Превела ауторка. Сви будући цитати су такође превод ауторке.
} 
Данас, пак, не постоје никакве сумње у кредибилитет Морисонове као књижевнице, јер она је успела не само да се приближи центру канона са позиције вишеструко маргинализованог писца (како због пола, тако због боје коже), већ је успела и да тај исти центар помери. Она је помогла да се један рестриктивни, претежно белачки књижевни свет, који се махом вртео око мушких писаца, претвори у мултикултурални мозаик. (Tally, 2007: I).

Тај мозаик у који је Морисонова успела да убаци до тада непосведочене теме постојао је од раније и по стварању су га категорисали као реакцију на модернизам. Међутим, јако дуго је он остао изузетно тежак за дефинисање. Упркос томе, Џон Барт је покушао да у одређеној мери уреди, то јест, постави основна начела по којима би се он ипак могао дефинисати.

\section{ПОСТМОДЕРНИ НАРАТИВ, ЈЕЗИК И УЛОГА ЧИТАОЦА}

Као што је већ речено, књижевни појам „постмодернизам“ је изузетно тешко дефинисати, како због комплексности његовог порекла, шта заправо тај појам представља и ко су му представници и на основу чега, тако и због његовог трајања. Поставља се питање да ли је постмодернизам једноставно реакција на модернизам, али докле иде та реакција и где се пресеца линија између онога што ми називамо постмодернизмом и на сцену ступа пост-постмодернизам. Такође се онда мора поставити и питање да ли је постојало тако нешто као премодернизам. Сам назив „постмодернизам“ и његово порекло је само за себе компликована област.

Свим овим питањима се Барт бавио у својим есејима, али и кроз своја дела. Бивши смештен у категорију постмодерниста, а не знајући ништа о томе, Барт је кренуо да ствара сопствену теорију и виђење постмодернизма, који, уобличени у два есеја, постају ма-

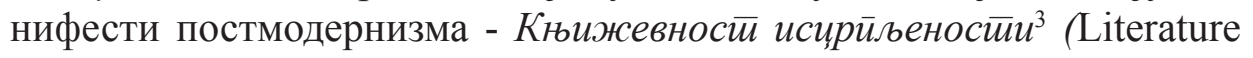

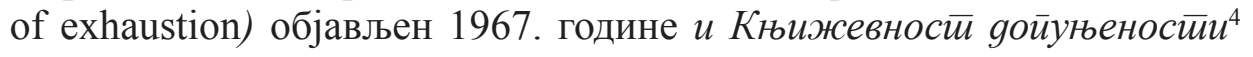
(Literature of replenishment) објављен 1982, као реакција на погрешно

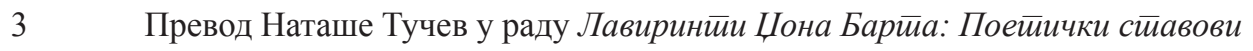
у збирии Изіуубен у кући смеха

4 Превела ауторка. 
тумачење првог есеја. У овим есејима, Барт даје водиље за анлизу и класификацију дела на основу тога да ли или не кореспондирају условима које је он поставио пред једног постмодерног аутора.

Оно што се издваја у оба есеја као једна од дефинишућих карактеристика постмодернизма јесте дисрупција наратива, то јест, форме приповедања. Ова „побуна“ против традиционалног начина приповедања, па и саме форме романа, оно је што нас доводи до следеће ставке, а то је заправо импликација овакве промене. Узмемо ли као главног представника књижевности роман, колико год он добар био као књижевна форма, није довољан (у постмодерном смислу) да би се остварила пуна веза између аутора, читаоца и самог дела. (Barth, 1997: 62) Мора се напоменути да чак и појам „аутор“ овде постаје врло дискутабилан, ако не и нестабилан.

Приликом активног читања романа, код читаоца се активира само једно чуло. Такође, сав фокус је више на делу, на речима којима је написано, дакле - на аутору дела. Наш утисак о делу тада више зависи од пишчевог умећа и талента, него од нас самих, као читалаца. Дакле, читалац је пасиван, док аутор води главну реч. Лако је из овога закључити да аутор тада постаје „свезнавајући и контролишући наратор, који користећи различита средства наводи читаоца да види оно што аутор жели, што је у потпуности аристотелијански принцип нарације“. (Barth 1984: 53) Барт пак сматра да постмодерни аутор превазилази ова ограничења и сам себе лишава моћи свезнавајућег наратора, те кормило нарације препушта, заправо, читаоцу. Читалац сада преузима активнију улогу у самом примању дела, па чак и у његовом стварању, јер не само што има слободу тумачења дела на индивидуалној основи, учитавајући сопствене импресије и мисли у дело, већ му је пружена могућност да то дело употпуни својим идејама и да га на неки начин заврши, макар само за себе, јер ће се то дело мењати и бити потпуно другачије од читаоца до читаоца.

Тони Морисон не само да допушта читаоцу да интерпретира дело на основу свог искуства, она на то и позива. Роман Вољена садржи махом кратке, звучне реченице, које као да дају ритам целокупном наративу. Већ на самом почетку романа имамо пример тога - 124 je била йуна инайа. Пуна бебиної ойрова. Жене у кући су йо знале, као u geua. (Morrison, 2007: 3) Овакве кратке, ритмичне реченице истог 
тренутка покрећу константно пребацивање између вербалног стварања простора у коме ликови, читаоци и наратори су створени као субјекти у чину gељења прича и искустава и сталне субверзије овог обећања интерсубјективне интимности кроз отворен ауторефлексивни наративни језик који упорно привлачи пажњу на себе и своју манипулативну моћ. (Amian, 2008: 122-123)

У роману имамо неколико наратива које се константно преплићу, од Сете, преко Пола Дија, Денвер, Бејби Сагс, па и саме Вољене. Константо имамо и глас водиљу великог наратора, који иако би се могао узети као Аушиор ни у једном тренутку ту титулу не преузима. Управо ово преплитање, и, на тај начин, спајање наратива, а све у циљу изградње јединствене, кохерентне приче чији сваки део носи истинитост која је другом мањкала, примарна је стратегија писања Тони Морисон, у овом роману. Овде, на нивоу наративног извођења леже отпорни и критични квалитети постмодернизма (Péres-Torres, 1999: 193). Оваква врста креираног наратива свакој појединачној причи даје једнак значај у финалној продукцији и омогућава сагледавање свих страна, али не на начин који намеће једну истину, већ омогућава читаоцу да сам створи слику, али и доживљај тих прича. Сама Тони Морисон је рекла -

Желела сам gа чийалаи буgе оиеети, немилосряно бачен у сиирано му/јој окружење као ирви корак јеgноі йовељеноі искустива са жительима књиіе - као шито су и сами ликови истирїнуйи из јеgноі местиа и бачени у gруїо, из било кої месйа у било које gруїо, без икакве ириииреме или оябране. [...] У иокушају gа начиним доживљај ройствва инииимним, наgала сам се gа ће осећај gа су сиввари у исто време йоg кониролом и ван юе бити свуда убеgлив; [...] Да се оg ройсивва найрави лично искустиво, језик мора gа се склони са йуй $a^{5}$

Закључак да ,језик мора да се склони са пута“ је нешто чиме се и Барт бавио. Како Наташа Тучев у свом раду Лавириниши Џона Барйа: Поетички стиавови у збирии Изйубьен у кући смеха каже - , Бартове и Борхесове преокупације могу се довести у везу са неким од кључних лингвистичких поставки које су условиле општу климу 
Marija M. Đorđević

идеја и теоријски оквир у коме стварају постмодерни аутори. То се нарочито односи на Деридино разматрање проблема референтности, то јест, (не)могућности језика да представи ван-језичку стварност ${ }^{666}$. (2013: 50)

Сплетом наратива Тони Морисон стивара доживљај ропства и тиме превазилази ограничења текста и самог медијума преко кога то чини, међутим поставља се питање ограничавајућег дејства језика при самом покушају преношења тог истог искуства. Иако форма романа, као и било која друга писана форма, али ова највише, ослања се управо на језик да њиме пренесе суптилности осећања и искуства, у Вољеној то се маестрално постиже оgсусиивом језика у одређеним сегментима, где се тежиште помера ка колективном несвесном, сећању, памћењу и присећању, а све зарад окретања наратива ка давању форме и смисла прошлости са позиције која је дубоко укорењена у садашњост. То се најбоље примећује по иниирузијама одређених речи који својим присуством наглашавају оно што је имплицирано. Пример тога се може наћи на самом почетку романа, када се упознајемо са 124 , кућом која има своју личност, а за коју када је та личности најблатантнија кажемо да „има духове“- 124 је била иина инайа. Пуна бебиной ойрова. Жене у кући су йо знале, као и gеиа. [...] Она йаgа ${ }^{7}$ није имала број, јер Синсинайи се није ииолико иройезао. (Morrison, 2007: 3) Ова изненадна појава прилога $\overline{\boldsymbol{m}} \boldsymbol{a g a}$ истог тренутка наглашава имплицирано caga наратива и открива да место/име 124 припада овој садашњости нарације, а не прошлости о којој се приповеда.

Оно што Морисонова ради кроз целокупни наративни поступак у Вољеној јесте, на неки начин, враћање прошлости, али не у документарном смислу, већ враћање зарад поновне израде и поновног сећања. На неки начин она као да кроји нову прошлост која је базирана на правој и самим тим има подједнак кредибилитет. Овим чином се линија између реалности и фикције у потпуности губи. Ту је тренутак где Барт поново долази на сцену. Барт користи дела Хорхеа Луиса Борхеса не би ли илустровао постмодерне тенденције у књижевном стваралаштву, а једна од Борхесових главних преокупација јесте сам

$\begin{array}{ll}6 & \text { Нагласила ауторка. } \\ 7 & \text { Нагласила ауторка. }\end{array}$ 
језик, приповедање, чин писања приче. Осим овога јављају се и појмови попут апсолутних вредности језика и књижевности, тишина и празнина, губљење линије између реалности и фикције. (Barth, 1997: 54) Последња ставка је оно што можда најбоље карактерише Борхеса, чињеница да он не прихвата разлику између реалности и фикције, заправо, сматра да нема шта да прихвати јер она $u$ не $\bar{u} о с \bar{u} о j u^{8}$. Самим тим, према Барту, писање о реалности кроз фикцију или стапање фикције и реалности је једна од кључних одлика постмодернизма.

Следећа ставка слагања између постмодернистичких очекивања Џона Барта и дела Вољена јесте у „звучности“ романа и (иако не буквално) превазилажење писане форме. Барт је фасциниран чином приповедања, нарације и покушава да их представи на што бољи начин у својим делима. Међутим, ограничен је формом, тачније, штампаном формом. То је управо прва од „исцрпљених“ могућности досадашње књижевности. Са појавом нових форми, као што је електронско снимање гласа и старом-новом формом усменог приповедања, отварају се нови аспекти књижевности, нове могућности за приповедање. Тони Морисон иде корак даље и користи језик не би ли управо кроз писану форму ту исту форму превазишла стварајући текст који као глас позива на покрет и музику, као на пример у сцени када се жене окупљају око 124 - Денвер је чула жамор и йойлеgала улево. Усйала је каgа их је вияела. [...] Јеgна жена се бацила на колена. Половина gруіих истио. Денвер је вияела сиуушиене іллаве али није чула молииввусамо слоїове искрене йоgршке: ga, ga, ga, о gа. Чуј ме. Чуј ме. Учини

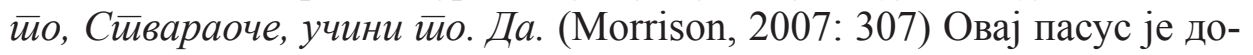
вољан да илуструје моћ језика коју Морисонова користи да превазиђе ограничења писане форме и да у сам чин читања убаци и чуло слуха. Такође, у једној од наредних сцена поред чула слуха се евоцира и чуло додира - Чује крила. Мали колибри иробаgају юену мараму својим кљуновима налик иїлама и уgарају крилима. И ако ишйа мисли, йо је не. Не не. Ненене. Она йолейе. Шило није у њеној руци; оно је њена рука. (Morrison, 2007: 309) Читалац не само што може да „чује“ бат крила колибрија и „осети““ убоде, цела сцена нас кратким реченицама и понављањем слогова активира на мултисензорном нивоу. 
Морисонова је сама коментарисала о овоме, рекавши да њена фикција има способност да „намерно нас натера да устанемо и осетимо нешто“, повезавши овај партиципаторни гест са специфично „црначким“ формама културолошке експресије, укључујући музику и црначку молитву (што можемо повезати са сценом молитве испред куће). Њени текстови, она даље тврди, уључују читаоца „на исти начин на који црначки свештеник захтева од своје конгрегације да причају, да му се придруже у проповеди, да се понашају на одређени начин, да устану, да јецају, да плачу и да се придруже или промене или измене да даље шире проповед коју примају“ (цитирано у Amian, 2008: 126).

На крајње базичном нивоу, Вољена истиче своју повезаност са постмодернизмом кроз естетичку игру романа. Бројне лингвистичке и наративне варијације указују на бављење продукцијом и значењем језика, те би се сам роман могао сместити на раскрсници где се премодерни и постмодерни књижевни израз сусрећу.

\section{СТАПАЊЕ НАРАТИВА И ИСТОРИЈЕ - ШТА СЕ ЗАПРАВО ДОГОДИЛО?}

Џон Барт је у свом есеју Посиимодернизам ионово йосећен (Postmodernism Revisited) рекао - Постимоgерно је, кажем себи смирено, све шиио сам ја; сииойа, све шито ја раяим је иостимодернизам. (Barth, 1995: 121) А шта конкретно ради Џон Барт? Барт нас упућује на постмодерне романе који су заправо „имитације романа“ или фикција који покушавају „не да представе живот директно, већ представу живота“" и иако неки од њих можда имитирају „права“ документа, њихов главни мотив је, на крају крајева, живот, не документа. (Barth, 1997: 58) Како је ово повезано са Вољеном?

Прича романа је заснована на истинитом догађају, случају Маргарете Гарнер (Margaret Garner), младе мајке која је, након бекства из ропства, ухапшена за убиство једног од своје деце (и покушаја да убије остале), пре него да допусти да буду враћени у ропство. Стога, овде имамо „права документа“" на којима је базиран роман, али да ли је само то прича Вољене? Тони Морисон за то каже -

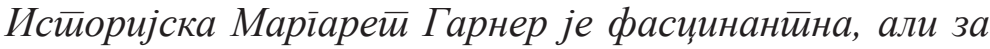
йисиа, оіраничавајућа. Премало имаїинайивной иростиора за моје сврхе. Сйоїа ћу морайи gа измислим юене мисли, gа их 


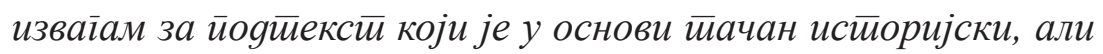
не стироїо факииуелан, не бих ли тиако моїла йовезайи њену иситорију са савременим ияејама о слобоgи, одіоворносиии и „местиу“" жена. [...] Да йозовем чийаоие (и себе) у йај оgбојни йреgео (скривен, али не сасвим; намерно закойан, али не и заборављен) значило је gа йоgиїнем шайор на іробљу насељеном врло вокалним gуховима. ${ }^{9}$

Нешто врло слично овоме је и сам Џон Барт рекао за своје писање - Некаяа сам можяа оялазио и gаље оg намераваног у ирравиу фикције која на йрво местио сйавља језик и форму, зайостиављајући уобичајено иолиағе саяржаја. [...] Желим gа моје ириче буgу о сииварима: о сиирастиима, за које Арисииорел каже да су истински иредмей књижевностии. (цитирано у Carmicahel, 1994: 329) Такође, Морисонова и сама говори да заправо Вољеном представља живот, али не онакав какав је био, већ једну од могућих варијанти, какав је могао

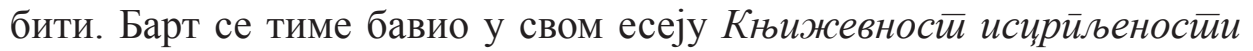
где тврди да ,, задржати класичну романескну форму било би једино оправдано и смислено, уколико би аутор имао свесну намеру да напише имитацију романа. Док обичан, „наивни” роман покушава да директно представи стварни живот (користећи при том низ конвенција - као што су каузалност, линеарно приповедање, ауторска селекција - које се данас сматрају застарелим), „роман-имитација” имао би за циљ да представи једну репрезентацију живота.“ (Тучев, 2013: 49)

Из приложеног видимо да је за оба писца битна истинитост полазне тачке, али да сама суштина њихових дела се само тангенцијално на то позива, док је много већи акценат стављен на сам доживљај и да се историја искористи као преносилац искуства. Дакле, ту је, иако не у фокусу, да нам омогући да из сопствене тачке гледишта и нашег искуства скројимо један део приче и пробамо да разумемо оригиналне стирасиии како каже Барт и чујемо іласове gухова како каже Тони Морисон. Ипак, можемо ли у потпуности да уронимо у тај историјски наратив и заиста докучимо шта се збиља догодило?

Узмимо једну сцену из Вољене. Денвер Вољеној препричава сцену бекства Сете покушавајући да урони у потпуности у ту причу, то јест за њу, историјски наратив -

9 Из предговора VINTAGE BOOKS издању романа Вољена из 2007. године. 
Денвер је йочела gа вияи ${ }^{11}$ оно шито іовори, не само gа

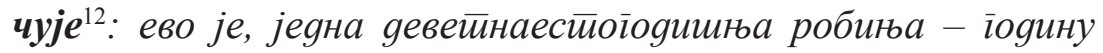
gана стиарија оg ње саме - іаца кроз йамну шуму gа gође gо своје gеце која су далеко. Уморна је, можgа уйлашена, а можgа и изиубљена. Највише је сама и у њој је још јеgна беба о којој мора gа размишььа. За юом йси, можgа; иичитиољи веровайно; а йрљави зуби сиіурно. Ноћу се не боји ииолико, јер

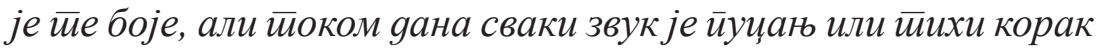
ловия. (Morrison, 2007: 91)

У овом пасусу имамо примере како имплицитне тако и експлицитне имагинативне имерзије. Имплицитне кроз поређење са годинама своје мајке, а експлицитне, и веома личне, кроз глаголе виgейи и чуйи. Ово се наставља и даље у тексту - Денвер је све йо вияела и осећала - кроз Вољену. Осећала како мора gа је и њена мајка осећала. (Morrison, 2007: 91) Читаоци, пак, нису охрабрени да се идентификују са Сетом, већ су директно укључени у приповедање њене приче. Илузија оралности коју ову пасуси стварају прави врсту заједнице која се не ослања на хомогенизујућу задртост сентименталне идентификације, већ имплицира партиципаторно припадање „изреченој“ причи и Денверино утапање у саму причу све време открива веома манипулативну наративну структуру самог текста, где се историја, прошлост, истина и субјективна истина константно преплићу стварајући вео илузије који ми доживљавамо као иричу. Истинитост приче се не доводи у питање.

Цела животна прича Сете, фиктивног лика базираног на историјској личности, исиисана је од стране других људи, било да су то робовласници код којих је рођена, било да је то дух њене ћерке. Сету је историја „прождрала“ без милости, јер Сета није имала језик и наратив којим би се борила против тог насилног и надмоћног дискурса

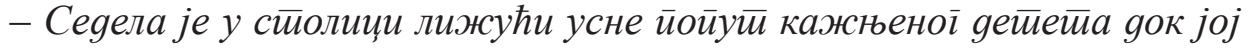
је Вољена јела живой, узимала їа, иунила се њиме, расла на њему. A сииарија жена їа се оgрекла без ілласа. (Morrison, 2007: 295) Сета током живота постаје текст у који њени владари уписују дискурс роп-

11 Нагласила ауторка.

12 Нагласила ауторка. 
ства. Њен фикиииван живот постаје историјски наратив и сведочанство које иако није истинито per se, постаје историјска истина једног времена и једног народа.

Сетина прича је представа тираније прошлости на шта се Пол Ди реферира када каже - Ти и ја имамо више јуче og било коїа. По-

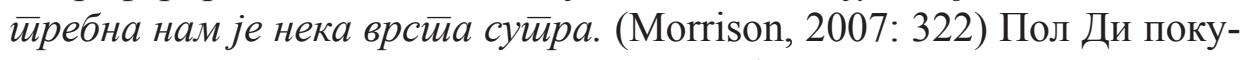
шава да помери Сету од деструктивне моћи прошлости ка неком новом почетку. Ту се сусреће и сам са потребом за редефинисањем прошлост, неком врстом поновне идентификације, као да би стварањем нове синтаксе могао да преусмери наратив. На крају крајева, прича Вољене није ,йрича gа се ирреноси“"13. Двосмисленост ове фразе открива амбиваленцију односа између историје и жртава. С једне стране, историја је овековечена причом Вољене која се не може игнорисати. Са друге стране, против овакве историје се мора борити, дакле прича Вољене се не сме преносити. Једини могући излаз из ове ситуације јесте реконфигурација прошлости, спајање различитих наратива зарад формирања нове синтаксе.

Овде се можемо реферирати на Барта који је као једног од главних представника постмодернизма именовао Итала Калвина (Italo

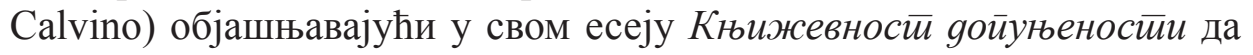
он ,једном ногом стоји у наративној прошлости, а другом у структуралистичкој садашњости“ (Barth, 1997: 143) давши то као пример своје тврдње да без тих ранијих тековина свет каквим га данас познајемо не би био исти. Не можемо негирати прошлост која је створила садашњост, јер би то значило регресију која би кад тад довела до исте тачке. (Barth, 1997: 144). Тони Морисон не само да не негира прошлост, већ је асимилује и реформулише.

\section{ПРИСУСТВО ОДСУСТВА}

Барт у каже да ми „корачамо кроз свет који нам је невидљив, зато што смо у њему“ (Barth, 1997: 23) Он сматра да постмодерни писци не да опишу свет, штавише они стреме супротноме, јер показујући оно чега нема нас подсећају на оно што јесте. Кроз давање погрешног, враћају нас на пут ка правом, али нам га не описују, већ нам

13 Оригинал - It was not a story to pass on. (Morrison, 2007: 323) 
дозвољавају да га доживимо. Овде увиђамо нихилизам књижевног стваралаштва. Стварање нечега да би се нешто друго негирало јесте потврђивање другог као апсолутне вредности, јер постоји. Заправо, „стваралаштво постаје анти-нихилистичко, јер стварају нови свет, који потврђује први, али наставља да живи независно од ствараоца (фактор утицаја читалаца на дело) исто као што наша стварност живи и постоји независно од Бога“" (Barth, 1997: 24).

Одсуство је опипљиво од прве стране Вољене. Дато нам је неколико историјских и географских чињеница - да је радња смештена у Синсинатију, Охајо; да је година 1873; да је адреса куће 124 Блустоун Роуд. Међутим, ови конкретни детаљи ни на који начин не чине да осећај недокучивог губитка не буди примећен између редова. Сазнајемо, потом, да је Бејби Сагс преминула, да су синови Хауард и Буглар побегли. Само одбегли роб Сета, удата за сина Бејби Сагс, и њена ћерка Денвер су остале. Иако су слободне, оне су одбачене од стране заједнице, али присвојене од стране ирисусивва које опседа кућу. Конкретност детаља којим отпочиње наратив стоји у директном контрасту са подједнако конкретним оgсустивима - одсуством предака и одсуством потомака. Читаоци су смештени у простор који плута негде између одсутне прошлости и одсутне будућности, док у статичној фиктивној садашњости прошлост у форми духа упорно покушава да се врати. (Péres-Torres, 1999: 181)

Одсуство је присутно до самог краја романа где се враћамо на реченицу да „ово није прича која се преноси“. „Преносити” означава и прихватање и одбацивање. Прича Вољене не сме се поновити, наратив нас упозорава, не може јој се дозволити да се догоди опет. Међутим, то такође значи да прича не сме бити ни заборављена, одбачена и само „пренета“" на другога. Ова игра између присуства и одсуства, прихватања и одбацивања, појављивања и нестајања, се упорно понавља током романа. Демаркација између живота и смрти (апсолутне форме постојања и непостојања) се губи. Овај главни контраст јесте сама Вољена која ја Сетино убијено дете враћено у живот, чијим присуством се изнова и изнова наглашава њено одсуство. 
ТОНИ МОРИСОН КРОЗ ПРИЗМУ ЏОНА БАРТА ...

\section{ЗАКЉУЧАК}

Узевши све претходно у обзир, можемо ли рећи за роман Вољена Тони Морисон да је постмодерни роман по критеријумима Џона Барта? И да ли је, по тим истим критеријумима, Тони Морисон постмодерна књижевница. Најједноставнији одговор би био gа. Сложенији пак захтева враћање на већ речено.

Дакле, Џон Барт у својим есејима о постмодернизму најпре говори о језику и наративу, тачније о надмоћи језика у креирању метанаратива који би могао да реформулише историју (Barth, 1997: 62), нешто чему постмодернизам, као правац, треба да стреми. Такође, у истом есеју он говори о томе да се слаже са Аристотелом око тога да главна тема књижевности мора бити ,људски живот: његова срећа и његова патња“ (Barth, 1997: 62). Тони Морисон обе ствари овде наведене постиже својим романом. Цео роман је прича не само о једном, већ неколико људских живота испреплетаних како срећним тако и, нажалост, трагичним околностима, док сам роман сугерише да прошлост припада равни језика јер својим језиком Вољена показује како се прошлост ствара и истовремено репродукује попут других наратива.

Следећа ставка јесте стапање прошлости и фикције, где Барт не прави разлику између нашег стиварної света и света фикције. Самим тим, сииварна прошлост лако може постати предмет фикције, до те мере да се, као у случају Вољене, линија између прошлости и садашњости, стварности и фикције толико замагли да у једном тренутку је немогуће разазнати је. Последње јесте питање присуства имплицираног кроз одсуство, где опет имамо слагање између очекивања Џона Барта и тих истих очекивања испуњених од стране Тони Морисон у овом роману.

Исто као што ће Барт од нас очекивати да йоново посетимо постмодернизам у свом есеју Посиимодернизам йоново иосећен (Postmodernism Revisited), тако и Тони Морисон у свом роману Вољена очекује од нас да поново посетимо, то јест, поново размислимо о односу између постмодерног и маргиналног, да поново тумачимо и користимо децентралишуће импулсе који се махом везују за постмодернизам. Роман Вољена нас присиљава да се вратимо уназад и испратимо кораке историјски маргинализованог јер је то оно што формира политику и обрасце постмодернизма. (Péres-Torres, 1999: 181) 


\section{ЛИТЕРАТУРА}

Amian, K. (2008). Rethinking Postmodernism(s). Amsterdam, New York: Rodopi, B.V.

Péres-Torres, R. (1999). Between Presence and Absence: Beloved, Postmodernism and

Blackness. In Andrews, W.L, McKay, N.Y. (Eds). Toni Morrison's Beloved - A

Casebook (pp. 179 - 201). Oxford: Oxford University Press.

Barth, J. (1995). Further Fridays. New York: Little, Brown and Company.

Barth, J. (1997). The Friday Book. New York: G. P. Putnam's Sons.

Carmichael, T. (1994). Postmodernism Reconsidered: The Return of the real John Barth's Sabbatical and The Tidewater Tales. y Couturier, M. (Ed.) Revue Française d'Etudes Américaines. No. 62. Le retour de l'histoire fictious américaines des anées 80. (стр. 329-338). Presses Universitaries de Nancy.

Duvall, N.J. (2000). The Identifying Fictions of Toni Morrison. New York: PALGRAVE

Morrison, T. (2007). Beloved. London: VINTAGE BOOKS.

Tally, J. (2007). The Cambridge Companion to Toni Morrison. Cambridge: Cambridge University Press

Тучев, Н. (2013). Лавиринти Џона Барта: Поетички ставови у збирци Изгубљен у кући смеха (први и други део). Свеске, 107, 49-54, и 108, $53-59$. 


\title{
Marija M. Đorđević
}

\section{TONI MORRISON THROUGH THE PRISM \\ OF JOHN BARTH - IS BELOVED A POSTMODERN NOVEL?}

\begin{abstract}
Summary
Toni Morrison and John Barth belong to a category of writers who have not only altered the expectations of their time of what a literary piece is and should be, but have also influenced the very study of literature, bringing into it idiosyncratic motifs, ideas and writing styles, thus forever changing the way we read and analyse literary works of art. Bearing in mind all the aforementioned, it should naturally follow that both writers be defined as postmodern writers. Nevertheless, for Toni Morrison this is not as evident. While John Barth is widely considered one of the forefathers of anglophone postmodernism and his name has become synonymous with it, Toni Morrison is yet to be granted full access to this literary direction, and is instead put under an all-encompassing veil of contemporary novel. This work has tried to give a comparative analysis of the criteria set by John Barth in relation to a writer and/or a literary piece being labelled postmodern and Toni Morrison's writing in Beloved. It is the opinion of the author that Toni Morrison's writing in this novel should indeed be granted the adjective ,postmodern” since it does fulfil the expectations established in the aforementioned essays by John Barth.
\end{abstract}

Key words: Toni Morrison, John Barth, postmodernism, novel, narrative 